\title{
PENGEMBANGAN ASSESSMENT UNTUK MENGUKUR KEMAMPUAN LITERASI SAINS PADA MATERI INTERAKSI MAKHLUK HIDUP DENGAN LINGKUNGANNYA DI SMPN Se-KOTA BENGKULU
}

\author{
Lydea Eftiwin ${ }^{1}$, Ahmad Walid ${ }^{2}$ \\ ${ }^{1}$ Department of Science Education, IAIN Bengkulu. \\ ${ }^{2}$ Early Childhood Education, IAIN Bengkulu. Bengkulu Indonesia \\ Corresponding : lydeaherman999@gmail.com
}

DOI : 10.35719/vektor.v2i2.33

\begin{abstract}
Abstrak. Penelitian ini bertujuan untuk mengembangkan assessment untuk mengukur kemampuan literasi sains pada materi interaksi makhluk hidup dengan lingkungannya. Metode penelitian yang digunakan adalah metode penelitian dan pengembangan yang teridiri dari 8 langkah, yaitu penelitian dan pengumpulan informasi awal, perencanaan, pengembangan format produk awal, uji coba skala kecil, revisi produk, uji coba awal, dan produk akhir. Subjek uji coba dalam penelitian dan pengembangan ini adalah subjek ahli, yaitu ahli assessment, ahli materi dan ahli bahasa, serta subjek sebanyak 60 siswa kelas VII SMPN se-Kota Bengkulu sebagai pengguna produk. Data dianalisis secara deskriptif kualitatif dan kuantitatif. Kelayakan assessment oleh tiga ahli validator yang dikembangkan pada aspek assessment sebesar $89 \%$, aspek materi sebesar $92 \%$, dan aspek bahasa $92 \%$, secara keseluruhan dinyatakan sangat layak dengan ratarata sebesar $91 \%$. Hal ini menunjukkan bahwa assessment literasi sains untuk mengkur kemampuan literasi sains dinyatakan sangat layak digunakan untuk mengukur tingkat kemampuan literasi sains peserta didik.
\end{abstract}

Kata kunci : Pengembangan Assessment, Literasi Sains

\begin{abstract}
This study aims to develop an assessment to measure scientific literacy skills in the interaction of living things with their environment. The research method used is a research and development method consisting of 8 steps, namely research and initial information collection, planning, initial product format development, small-scale trials, product revisions, initial trials, and final products. The trial subjects in this research and development are expert subjects, namely assessment experts, material experts and linguists, as well as the subjects of class VII SMPN students in Bengkulu City as product users. Data were analyzed descriptively qualitatively and quantitatively. The feasibility of the assessment by three validator experts developed in the assessment aspect of $89 \%$, material aspect of $92 \%$, and language aspect of $92 \%$, all of which were declared very feasible with an average of $91 \%$. This shows that the scientific literacy assessment to measure scientific literacy ability is stated to be very suitable to be used to measure the level of students' scientific literacy ability.
\end{abstract}

Keywords: Assessment Development, Scientific Literacy

\section{PENDAHULUAN}

Dalam menyiapkan sumber daya manusia yang berkualitas, maka pendidikan merupakan salah satu faktor penting dalam mendukung pembangunan nasional, sesuai dengan tujuan dan cita-cita mencerdaskan kehidupan bangsa yang tercantum pada pembukaan UUD 1945 alinea keempat. Pendidikan juga merupakan hak dan kewajiban dari setiap warga negara Indonesia. Hal tersebut dijelaskan dalam UU SISDIKNAS No. 20 Tahun 
2003 Pasal 5 Ayat 1 disebutkan bahwa setiap warga negara memiliki hak yang sama untuk memperoleh pendidikan yang bermutu (Kartika, Eftiwin, Lubis, \& Walid, 2020).

Pada abad 21 pembelajaran lebih menekankan setiap orang untuk belajar dan berpikir, dengan fokus pada pengembangan kemampuan intelektual sehingga mampu beradaptasi dengan perubahan dan perkembangan zaman (Walid, Sajidan, Ramli, \& Kusumah, 2019). Pendidikan diharapkan mampu menumbuhkan keterampilan berpikir logis, kreatif, adaptif dan inisiatif terhadap perubahan dan perkembangan (Bagiarta, Karyasa, \& Suardana, 2015). Di Indonesia pendidikan tergolong masih rendah jika dibandingkan dengan negara-negara berkembang lainnya. Hal ini dapat dilihat dari pendidikan sains yang menunjukan rendahnya pencapaian tingkat literasi sains dalam PISA (Program for International Student Asassemen). PISA merupakan sistem ujian yang diinisasi oleh Organisation for Economic Cooperation and Development (OECD) (Zahro', 2020). Berdasarkan laporan PISA tahun 2018 Indonesia berada di peringkat ke 70 dari 77 negara untuk skor sains (Organisation for Economic Cooperation and Development (OECD), 2018).

Salah satu keterampilan yang penting dimiliki pada abad 21 adalah literasi sains. Literasi sains merupakan kemampuan untuk menggunakan pengetahuan yang dimilikinya untuk mengidentifikasi masalah, memperoleh pengetahuan baru, menjelaskan fenomena ilmiah, dan menarik kesimpulan berdasarkan bukti yang berhubungan dengan isu ilimiah (Toharudin, Hendrawati, \& Rustaman, 2011). National Center for Education Statistics (NCES) menyatakan literasi sains merupakan pengetahuan dan pemahaman konsep serta proses ilmiah yang diperlukan dalam membuat keputusan secara personal, berkontribusi dalam kegiatan kebudayaan dan kemasyarakatan, serta produktivitas ekonomi. Sejalan dengan pendapat sebelumnya, Gormally juga mendefinisikan literasi sains sebagai kemampuan seseorang untuk membedakan fakta-fakta sains dari bermacam-macam informasi, mengenal dan menganalisis penggunaan metode penyelidikan saintifik serta kemampuan untuk mengorganisasi, menganalisis, menginterpretasikan data kuantitatif dan informasi sains (Winata, Cacik, \& W., 2018).

Literasi sains didefinisikan dalam PISA 2018 sebagai kemampuan memberikan ide-ide ilmiah untuk terlibat dalam isu-isu terkait ilmu pengetahuan dalam rangka menyelesaikan permasalahan atau isu-isu tersebut dalam kehidupan, sebagai manusia yang reflektif (Organisation for Economic Cooperation and Development(OECD), 2016). Literasi sains bukan semata-mata kemampuan untuk memahami ilmu pengetahuan ilmiah, tetapi juga kemampuan untuk memahami proses sains dan diaplikasikan untuk menghadapi kondisi nyata yang terjadi di lingkungan (Rostikawati, 2016). Salah satu upaya untuk mengukur kemampuan literasi siswa terutama dalam bidang sains yaitu dilakukannya penyusunan assessment yang berbasis literasi sains. Penilaian atau assessment merupakan hal yang penting dalam pembelajaran, sebagai salah satu upaya meningkatkan kualitas pendidikan. Assessment dapat dinyatakan sebagai proses pengumpulan data yang dapat menunjukkan kemajuan belajar siswa. Terdapat beberapa istilah yang berkaitan dengan assessment yaitu performance assessment, assessment alternatif dan assessment otentik (Gloria, 2012).

Terkait dengan belum dikembangkannnya assessment literasi sains, khususnya apabila dikaitkan dengan survei benchmarking internasional seperti PISA. Menurut Fencl dan Chevalier, berdasarkan beberapa studi berkaitan dengan pengembanagna kemampuan literasi sains siswa yang telah menggunakan soal ujian pilihan ganda atau pre-test dan posttest sebagai alat penilaian (Gormally, Brickman, \& Lutz, 2012).

Hasil observasi yang peneliti lakukan di tiga SMPN berbeda se-Kota Bengkulu diperoleh informasi bahwa soal-soal yang dijadikan untuk mengukur hasil belajar siswa belum bermuatan literasi sains, soal tersebut lebih menekankan aspek konten dan belum memuat aspek proses dan konteks. Berdasarkan penelitian tersebut didapatkan bahwa tingkat literasi sains dilihat dari soal-soal yang disusun oleh guru masih tergolong rendah.

81| VEKTOR: Jurnal Pendidikan IPA, Vol. 02, No. 02, hlm. 80-86, 2021 
Hal tersebut di buktikan dengan hasil analisis soal, soal-soal yang memenuhi indikator literasi sains, yaitu sebesar :

\begin{tabular}{cc}
\hline Nama Sekolah & $\begin{array}{c}\text { Hasil Analisis Soal } \\
\text { Literasi Sains }\end{array}$ \\
\hline SMP A & $31 \%$ \\
SMP B & $25 \%$ \\
SMP C & $18 \%$ \\
\hline
\end{tabular}

Berdasarkan latar belakang tersebut maka peneliti tertarik untuk melakukan "Pengembangan Assessment Untuk Mengukur Kemampuan Literasi Sains Pada Materi Interaksi Makhluk Hidup Dengan Lingkungannya Siswa SMPN Se-Kota Bengkulu". Untuk pemilihan materi interaksi makhluk hidup dengan lingkungannya itu sendiri disesuaikan dengan materi yang sedang dipelajari peserta didik saat penelitu melakukan penelitian ini.

\section{Metode Penelitian}

Metode penelitian adalah metode penelitian dan pengembangan adalah metode penelitian yang digunakan untuk menghasilkan produk tertentu dan menguji keefektifannya. Research and Development (RnD) atau lebih dikenal dengan penelitian pengembangan adalah suatu metode penelitian yang digunakan untuk menghasilkan produk tertentu, dan menguji keefektifan produk tersebut.

Penelitian pengembangan assessment ini dilakukan di Sekolah Menengah Pertama di Kota Bengkulu, yaitu SMPN 1 Kota Bengkulu, SMPN 8 Kota Bengkulu, dan SMPN 19 Kota Bengkulu. Penelitian pengembangan ini dilaksanakan dari tahap persiapan sampai tahap pelaksanaan, dimulai awal bulan April 2021 sampai Bulan Juni 2021.

Adapun langkah-langkah penelitian tersebut seperti ditunjukan pada bagan dibawah ini, :

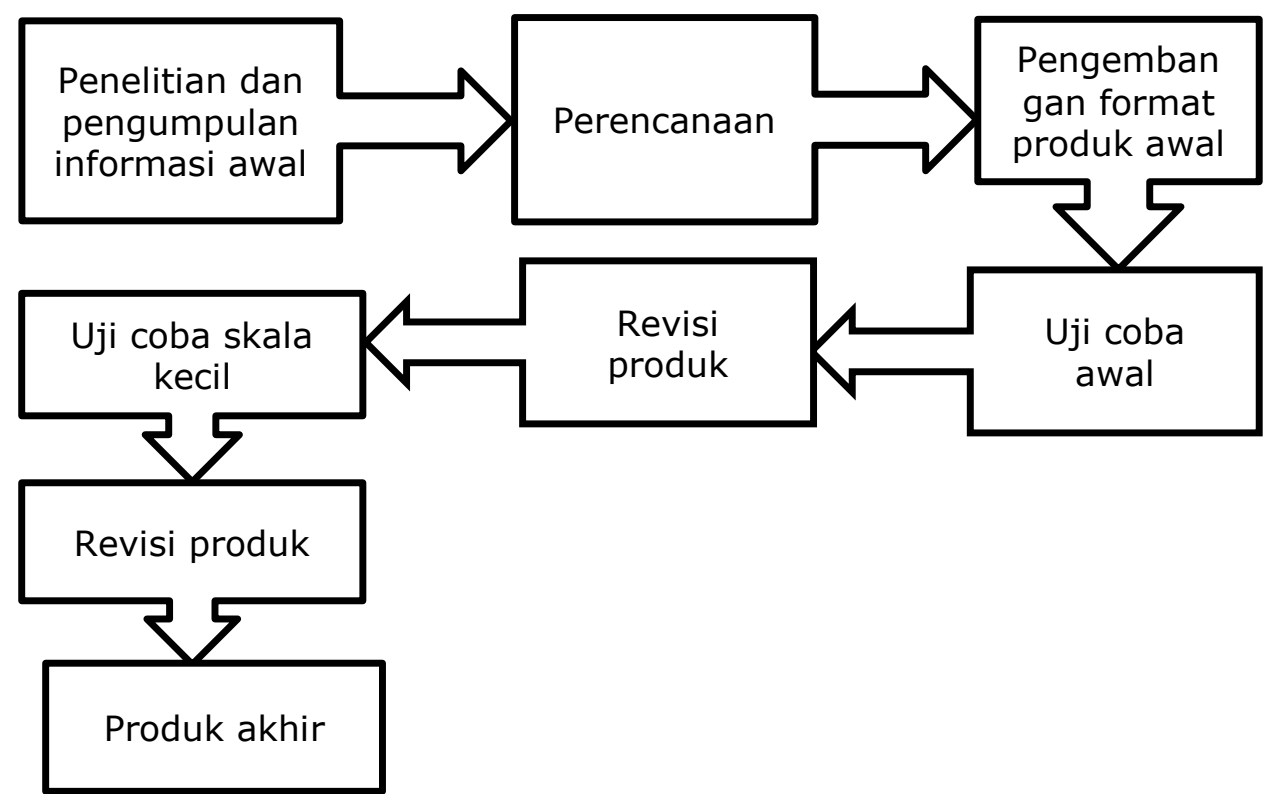


Bagan 1. Langkah-langkah penelitian

Dari sepuluh langkah yang ada peneliti akan membatasi dengan disesuaikan akan kebutuhan penelitian dan pengembangan yang dilakukan. Setelah disederhanakan prosedur penelitian dan pengembangan menjadi delapan langkah hanya sampai tahap pengembangan. Adapun gambaran produk akhir setlah dilakukan revisi sebagai berikut :

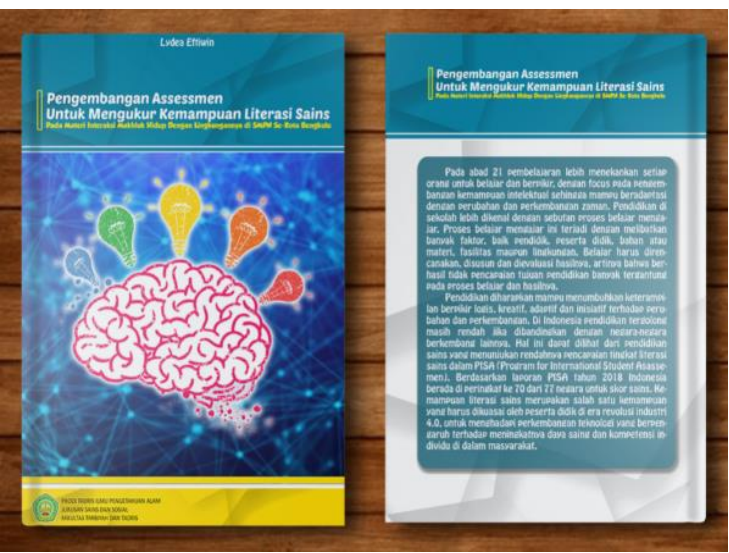

Gambar 1. Cover depan-belakang assessment

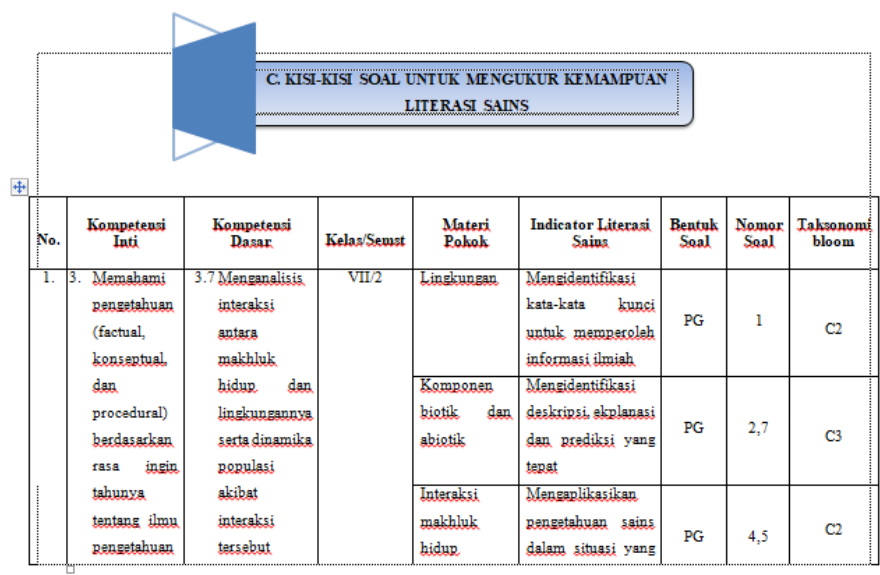

Gambar 2. Kisi-kisi assessment 


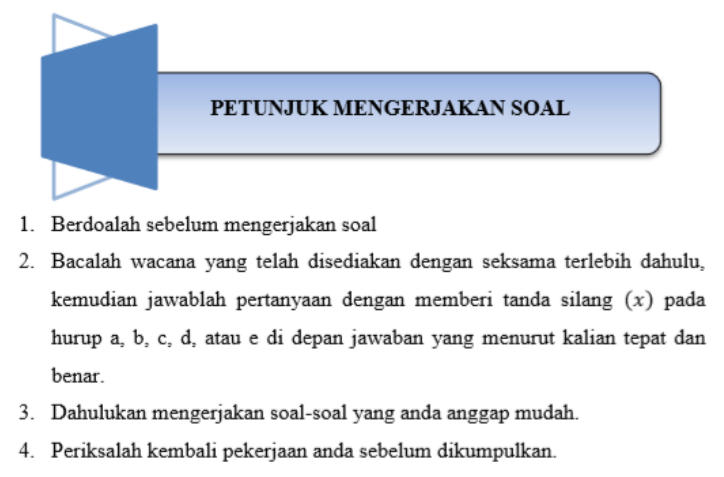

Gambar 3. Petunjuk Pengerjaan Soal
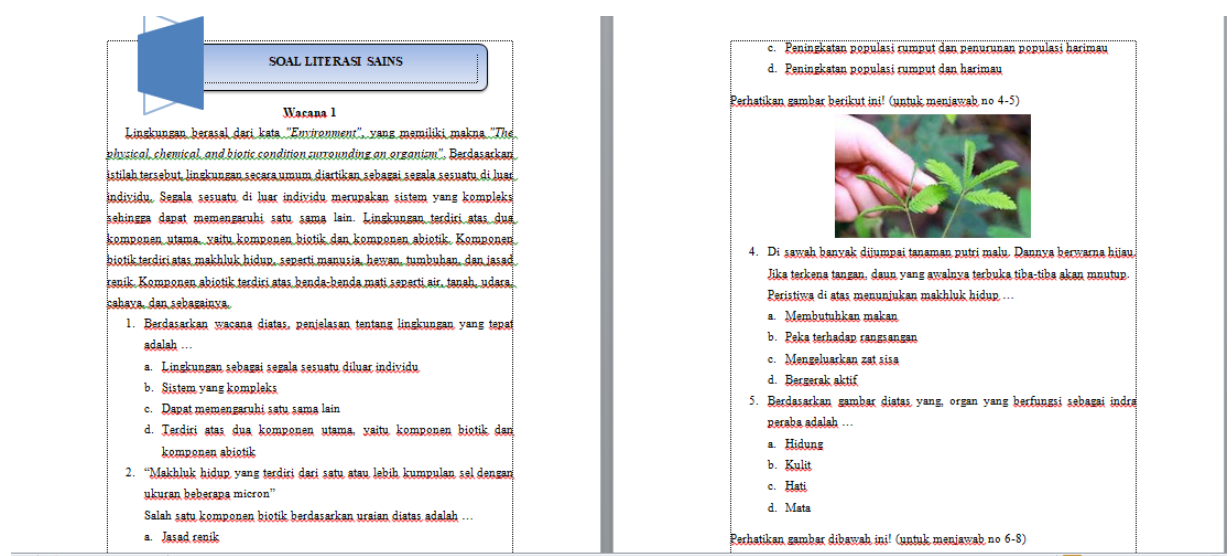

Gambar 4. Soal Tes Literasi Sains

\section{Hasil dan Pembahasan}

Validitas Assessment Untuk Mengukur Kemampuan Literasi Sains ditentuka $\mathrm{n}$ oleh validasi ahli yang dilakukan oleh tiga dosen ahli (assessment, materi dan bahasa). Validitas dilakukan untuk mengetahui kelayakan produk yang akan digunakan dalam penelitian. Menurut Kunandar (2014), instrumen yang valid dapat mengukur secara tepat apa yang akan dikur. Oleh karena itu, validitas dilakukan oleh dosen yang benar-benar ahli dalam bidang materi interaksi makhluk hidup dengan lingkungannya. Menurut Fariyani (2015), pengujian validitas dilakukan pada setiap butir soal dengan tujuan untuk mengetahui apakah instrumen tes benar-benar layak digunakan untuk mengukur apa yang akan diukur.

Butir soal dinilai secara detail dapat mempermudah dalam mengidentifikasi soal yang memerlukan perbaikan. Validitas setiap butir soal mencakup 13 aspek penilaian segi assessmen dan 8 aspek penilaian meliputi segi materi dan bahasa. Tiap aspek diberi skor 5 apabila aspek yang dinilai sangat baik, skor 4 apabila aspek yang dinilai baik, skor 3 apabila aspek yang dinilai cukup, skor 2 apabila aspek yang dinilai kurang, dan skor 1 apabila aspek yang dinilai sangat kurang. Selain itu, validator juga memberikan komentar dan saran terhadap instrumen tes yang dikembangkan.

a. Validasi Ahli Assessment 
Validasi yang dilakukan oleh ahli assessment diggunakan untuk menilai produk assessment untuk mengukur kemampuan literasi sains. Adapun aspek yang dinilai oleh ahli assessment diantaranya kesesuaian dan kelengkapan produk. Aspek kesesuaian dan kelengkapan untuk menilai serta kemudahan dalam penggunaan. Penilaian ini bertujuan untuk melihat layak atau tidaknya assessment tersebut digunakan kepada siswa. Adapun hasil penilaian validasi dari ahli media dapat dilihat pada tabel dibawah ini.

Tabel 1. Validasi Ahli Assessment

\begin{tabular}{|c|c|c|c|c|c|}
\hline Validator & $\begin{array}{c}\text { Jumlah } \\
\text { Item }\end{array}$ & $\begin{array}{c}\text { Skor } \\
\text { Ideal }\end{array}$ & $\begin{array}{c}\text { Skor } \\
\text { Diperoleh }\end{array}$ & $\%$ & Kualifikasi \\
\hline 1 & 13 & 40 & 37 & 89 & $\begin{array}{c}\text { Sangat } \\
\text { Layak }\end{array}$ \\
\hline
\end{tabular}

Hasil nilai ahli dikriteriakan $X>81 \%$ (sangat layak), $61 \%<X \leq 80 \%$ (layak), $41 \%<X \leq 60 \%$ (cukup layak), $21 \%<X \leq 40 \%$ (kurang layak), dan $X \leq 20 \%$ (sangat kurang layak). Persentase produk akhir $92 \%$ dengan k riteria sangat layak. Maka dapat disimpulkan berdasarkan tabel di atas mengenai kriteria penilaian skor ratarata persentase, dapat dinyatakan bahwa hasil pengembangan assessmen untuk mengukur kemampuan literasi sains pada materi interaksi makhluk hidup dengan lingkungannya sangat layak dari aspek penilaian kelengkapan assessment.

b. Validasi Ahli Materi

Validasi materi diggunakan untuk menilai materi yang telah disusun dalam assessment untuk mengukur kemampuan literasi sains. Aspek pembelajaran dinilai untuk mengetahui apakah materi yang disajikan sudah sesuai dengan KI dan KD serta tujuan pembelajaran yang mencakup materi dalam satu semester. Sedangkan aspek isi untuk mengetahui apakah isi dari materi sudah jelas dalam penyajiannya. Adapun hasil penilaian validasi dari ahli materi dapat dilihat pada tabel dibawah ini.

Tabel 2. Validasi Ahli Materi

\begin{tabular}{|c|c|c|c|c|c|}
\hline Validator & $\begin{array}{c}\text { Jumlah } \\
\text { Item }\end{array}$ & $\begin{array}{c}\text { Skor } \\
\text { Ideal }\end{array}$ & $\begin{array}{c}\text { Skor } \\
\text { Diperoleh }\end{array}$ & \% & Kualifikasi \\
\hline 1 & 8 & 40 & 37 & 92 & $\begin{array}{c}\text { Sangat } \\
\text { Layak }\end{array}$ \\
\hline
\end{tabular}

Hasil nilai ahli pembelajaran dikriteriakan $X>81 \%$ (sangat layak), $61 \%<X \leq$ $80 \%$ (layak), 41\%<X $\leq 60 \%$ (cukup layak), $21 \%<X \leq 40 \%$ (kurang layak), dan $X$ $\leq 20 \%$ (sangat kurang layak). Persentase produk akhir $92 \%$ dengan kriteria sangat layak. Maka dapat disimpulkan berdasarkan tabel di atas. mengenai kriteria penilaian skor rata-rata persentase, dapat dinyatakan bahwa hasil pengembangan assessment untuk mengukur kemampuan literasi sains pada materi interaksi makhluk hidup dengan lingkungannya sangat layak dari aspek penilaian silabus dan aspek penilaian RPP.

c. Validasi Ahli Bahasa 
Validasi yang dilakukan oleh ahli bahasa diggunakan untuk menilai produk assessment untuk mengukur kemampuan literasi sains. Adapun aspek yang dinilai oleh ahli bahasa diantaranya penggunaan bahasa yang digunakan. Aspek penggunaan bahasa untuk menilai kosakata yang dipakai, kesesuaian dengan kaidah bahasa indonesia yang benar. Penilaian ini bertujuan untuk melihat layak atau tidaknya assessment tersebut digunakan kepada siswa. Adapun hasil penilaian validasi ahli bahasa dapat dilihat pada tabel dibawah ini.

Tabel 3. Validasi Ahli Bahasa

\begin{tabular}{|c|c|c|c|c|c|}
\hline Validator & $\begin{array}{c}\text { Jumlah } \\
\text { Item }\end{array}$ & $\begin{array}{c}\text { Skor } \\
\text { Ideal }\end{array}$ & $\begin{array}{c}\text { Skor } \\
\text { Diperoleh }\end{array}$ & \% & Kualifikasi \\
\hline 1 & 8 & 40 & 37 & 92 & $\begin{array}{c}\text { Sangat } \\
\text { Layak }\end{array}$ \\
\hline
\end{tabular}

Hasil nilai ahli bahasa dikriteriakan $X>81 \%$ (sangat layak), $61 \%<X \leq 80 \%$ (layak), $41 \%<X \leq 60 \%$ (cukup layak), $21 \%<X \leq 40 \%$ (kurang layak), dan $X \leq$ $20 \%$ (sangat kurang layak).Berdasarkan hasil pengembangan assessment untuk mengukur kemampuan literasi sains yang telah dilakukan, diketahui hasil dari validator terhadap diperoleh hasil 92\%. Sehingga dari hasil validator mengacu pada tabel konversi, maka dapat disimpulkan bahwa assessment untuk mengukur kemampuan literasi sains yang dikembangkan sudah layak diggunakan atau sudah dapat di uji cobakan kepada siswa dan tidak perlu lagi direvisi oleh peneliti.

Uji skala kecil dilakukan setelah merevisi instrumen tes sesuai saran validator. Tujuan uji skala kecil untuk mengetahui jumlah soal yang dapat digunakan pada uji skala luas, mengetahui waktu yang dibutuhkan untuk mengerjakan soal berbasis literasi sains serta menentukan daya pembeda, taraf kesukaran dan reliabilitas soal tes. Uji skala kecil melibatkan 60 peserta didik kelas VII di SMP Negeri se-Kota Bengkulu. Soal yang digunakan pada uji skala kecil berjumlah 20 butir soal pilihan ganda yang dikerjakan dalam waktu 90 menit. Hasil uji skala kecil dianalisis validasi soal, reliabilitas, daya pembeda, dan tingkat kesukaran.

\section{Simpulan}

Kelayakan assessment oleh tiga ahli validator yang dikembangkan pada aspek assessmen sebesar 89\%, aspek materi sebesar 92\%, dan aspek bahasa 92\%, secara keseluruhan dinyatakan sangat layak dengan rata-rata sebesar $91 \%$. Hal ini menunjukkan bahwa assessment literasi sains untuk mengkur kemampuan literasi sains dinyatakan sangat layak digunakan untuk mengukur tingkat kemampuan literasi sains peserta didik. Validitas butir soal yang dianalisis menggunakan aplikasi pemodelan rasch (winstep) menunjukkan bahwa butir soal keseluruhannya dalam kategori valid.

\section{Daftar Pustaka}

Bagiarta, I. N., Karyasa, I. W., \& Suardana, I. N. (2015). Komparasi Literasi Sains Antara Siswa Yang dibelajarkan Dengan Model Pembelajaran Kooperatif Tipe GI (Group Investigation) Dan Model Pembelajaran Inkuiri Terbimbing (Guide Inquiry) Ditinjau Dari 
Motivasi Berprestasi Siswa SMP. E-Journal Program Pascasarjana Universitas Pendidikan Ganesha Program Study IPA, 5.

Gloria, R. Y. (2012). Pentingnya Asesmen Alternatif Dalam Meningkatkan Kemampuan Berpikir Dan Membaca Ilmiah Siswa Pada Pembelajaran Biologi. Jurnal Scientiae Educatia, 1(1).

Gormally, C., Brickman, P., \& Lutz, M. (2012). Developing a Test of Scientific Literacy Skills (TOSLS): Measuring Undergraduates' Evaluation of Scientific Information and Argument. CBE-Life Sciences Education, 11.

Kartika, A. T., Eftiwin, L., Lubis, M. F., \& Walid, A. (2020). Profil Kemampuan Berpikir Kritis Siswa Kelas VIII SMP Pada Mata Pelajaran IPA. JARTIKA, 3(1).

Muhammad, Fauroni, R, L. (2002). Visi Al-Quran Tentang Etika dan Bisnis. jakarta: Salemba Dinyiyah.

Organisation for Economic Cooperation and Development(OECD). (2016). PISA 2015 Results in Focus. Paris: OECD.

Organisation for Economic Cooperation and Development (OECD). (2018). PISA 2015 draft frameworks. Paris: PISA, OECD Publishing.

Rostikawati, D. A. (2016). Rekonstruksi Bahan Ajar dengan Konteks SocioScientific Issues pada Materi Zat Aditif Makanan untuk Meningkatkan Literasi Sains Siswa. Jurnal Inovasi Pendidikan IPA, 2(2).

Toharudin, U., Hendrawati, S., \& Rustaman, A. (2011). Membangun Literasi Sains Peserta Didik. Bandung: Humaniora.

Walid, A., Sajidan, S., Ramli, M., \& Kusumah, R. G. T. (2019). Construction of The Assessment Concept to Measure Students' High Order Thinking Skills. Journal for the Education of Gifted Young Scientists, 7(2).

Winata, A., Cacik, S., \& W., I. S. R. (2018). Kemampuan Awal Literasi Sains Peserta Didik Kelas V SDN Sidorejo I Tuban pada Materi Daur Air. JTIEE, 2(1).

Zahro', U. R. (2020). Pengembangan Instrumen Tes Untuk Mengukur Kemampuan Literasi Sains Siswa SMP Pada Tema Pemanasan Global. Tesis Pasca Sarjana Universitas Negeri Semarang Prodi Pendidikan IPA. 